\title{
The Determinants of Electronic Textbook Use Among College Students*
}

\author{
Jon R. Miller \\ Andrew W. Nutting** \\ Lori Baker-Eveleth
}

April 2012

\begin{abstract}
Electronic books are a fast-growing component of the publishing industry. Sales of electronic textbooks (e-textbooks) are growing, but at a slower rate. In this research we use data from an undergraduate student survey to estimate the determinants of e-textbook use. We find that students who are younger, lower-income, and from larger high schools are more likely to use e-textbooks. E-textbooks are more likely to be used by students in the more technically-oriented colleges and especially in the college of Business and Economics, where electronic materials are often required. An environment of continued growth in student technical competence with information technology, continued increases in college cost and a reduction in professor resistance to e-textbooks would bode well for growth in the use of them.
\end{abstract}

JEL Codes: A22, C25, D12, I23

Keywords: college, e-book, e-textbook, electronic, logit analysis

*The authors are Professor of Economics, Assistant Professor of Economics and Associate Professor of Information Systems, respectively, at Department of Business, College of Business and Economics, University of Idaho, P.O. Box 443161, Moscow, ID 83844-3161.

**Corresponding author. 


\section{Introduction}

Electronic media appear to be winning the battle for readership in the United States, as bookstores close (Roso \& Rosenwald, 2011) and print newspapers downsize or go out of business entirely (Perez-Pena, 2009; Richman \& James, 2009). According to a recent sales report from the Association of American Publishers, adult e-book sales rose $49.4 \%$ in January 2012, more than triple the growth in mass market paperback sales. Sales of children's and religious e-books rose 475\% and 151\%, respectively (Association of American Publishers, 2012).

Sales figures for electronic textbooks (e-textbooks), a specific type of e-Book, are harder to find, but estimates suggest that their use is rising. According to the National Association of College Stores (2010), national e-textbook revenue in 2010 was 3\% of total textbook revenue (Foderaro, 2010), but that share was expected to grow to 10 or 15 percent by 2012 (Foderaro, 2010; Schuetze, 2011; Krapfl, 2011).

Rapid evolution characterizes the e-textbook market. In this research, we take a snapshot of this evolution by analyzing e-textbook use at a particular university at a particular time. Using data on individual students at the University of Idaho, we use logit analysis to answer questions about the determinants of e-textbook use. Why have some students used e-textbooks while others have not? Do different college majors influence use? Do students' backgrounds and socioeconomic characteristics affect e-textbook use?

The remainder of this paper is organized as follows. Section II discusses providers of etextbooks. Section III surveys the scant literature regarding students' propensities of using electronic textbooks. Section IV discusses the data collection process and summary statistics. Section V discusses the estimation strategy and results. Section VI concludes. 


\section{E-textbook Providers}

The number of providers of e-textbook content continues to expand. Digital publisher flatworldKNOWLEDGE has been in business since 2007. In May 2011, they list 35 titles with an expected doubling in the number of titles by spring 2012, according to Jon Williams, Chief Technology Officer at flatworldKNOWLEDGE (Hampson, 2011). The flatworldKNOWLEDGE textbooks are free to view online, or a student can pay for sections to be printed or the entire book for around $\$ 29.95$. CourseSmart, also began in 2007, and is a partnership of traditional book publishers, such as Cengage, Pearson and McGraw-Hill. Through the partnership, CourseSmart provides not only e-textbooks but an online catalog of electronic resources and other digital course material (Graham, 2011). The e-textbooks are available to purchase as a PDF for a 180-day subscription. Another e-textbook supplier, VitalSource, is supported by publisher Macmillan and provides a customizable textbook using a platform called DynamicBooks. These e-textbooks can be read on e-readers such as a Kindle or iPad.

Universities are experimenting with e-textbook programs. The University of Phoenix consolidated all course textbooks in an electronic library, charging $\$ 75$ a semester for electronic access to any textbook (Blumenstyk, 2008). Northwest Missouri State University ran a pilot program with 240 students who were loaned e-book reading devices and provided with electronic textbooks. The University of Idaho has tested a method where professors provide an electronic, custom text tailored to a specific course and charge for it with a course fee (BakerEveleth, et al., 2011). Open source programs, such as GNU Free Documentation License (GFDL), allow the authors of the content as well as readers to make suggestions and note errors and corrections (Beezer, 2009). 


\section{Literature on Determinants of E-Textbook Use}

In spite of the rapid growth and development of eBooks and e-textbooks, little research on it exists. What we know comes from student surveys and anecdotal evidence in the discussion of the pros and cons of e-textbooks and their print alternatives. For example, a report on research sponsored by the National Association of College Stores (NACS) noted that threequarters of students surveyed preferred a bound book to a digital version (NACS, 2010; Foderaro, 2010). Others find similar preferences. The current generation of college students is very comfortable with electronic information and communication of it, yet student surveys indicate a strong preference for hard copy texts (Nelson, 2008a; Dudley, 2011).

Some authors note that e-textbook sales growth could be limited by unique factors not facing regular e-Books. Graphics and mathematics, common in college texts, are more difficult to transmit on popular e-readers such as Amazon's Kindle. Hard copy books don’t get blank screens or viruses and they allow the reader to flip quickly through chapters and write easily in the margins (Foderaro, 2010). And if e-textbooks are not available on special readers, students resist being "tethered" to a computer and suffering eye strain and back and neck problems from reading on computer screens (Carlson, 2005; Crawford, 2006; Nelson, 2008b).

Some point to advantages of e-textbooks. They allow an environment where students can interact and engage with the material in a different way. Most digital books are searchable, can be highlighted like a traditional textbook, and often have a comment box or annotation ability on the pages (Ravid, 2008). E-textbooks are easier to update and edit. Traditional hard copy textbooks from publishers are limited in how quickly they can correct errors or make updates to the textbook (Larson, 2002; Stewart, 2009). 
The rising cost of hard copy textbooks appears to be causing students to consider electronic alternatives to traditional textbooks (Marklein, 2012). According to the U.S. Government Accountability Office (2005), between 1987 and 2004 the average price of a college textbook increased an average of $6 \%$ per year, twice as fast as the consumer price index. On average, a college textbook costs $\$ 125$, and many are not resalable on the used textbook market. The total textbook cost for a typical year of classes is close to $\$ 1,000$ (Christopher, 2009; Rampell, 2008). This increased cost creates financial pressure for college students and their families. Students, parents, state legislatures, federal agencies, university bookstores and book publishers have responded to rising textbook costs by making it an important and controversial issue on college campuses (Chaker, 2006; Kang, 2004; Kingsbury \& Galloway, 2006; Roberts, 2006).

\section{Data}

Data were collected via a web-based questionnaire in November 2009, at the University of Idaho. An invitation to participate was distributed via a listserv to $11,957 \mathrm{U}$ of I students. ${ }^{1}$ A total of 1382 responses were received, producing an 8.65\% response rate, and almost 1100 responses possessed complete enough answers to be included in this paper. Summary statistics for relevant variables derived from the questionnaire are presented in Table 1a. A total of 44.5\% of students had purchased or used an electronic textbook. Almost 60 percent of students were female, whereas under half of degree-seeking undergraduates at the University of Idaho are female (US News, 2012). The average student's high school had a graduating class of

\footnotetext{
${ }^{1}$ Data for this research are part of a larger study examining the psychological underpinnings of e-textbook use.
} 
approximately $270,^{2}$ and $7.4 \%$ of the sample graduated from a private high school. Approximately 65 percent of respondents received financial aid, and over two-thirds received scholarships. A majority, over 55 percent, worked either full-time or part-time while in school. Almost half of respondents received tuition assistance from parents or family.

Almost 93 percent of respondents owned a laptop computer. Fewer than 40 percent owned a desktop. About 8.5 percent of students reported that their professors "strongly disagreed" with the use of electronic textbooks, while 5.9 percent reported that their professors "agreed" or "strongly agreed" with their use. ${ }^{3}$ Over one-quarter of respondents were enrolled in the College of Letters, Arts, and Social Science, while the Colleges of Business and Economics, Education, and Engineering each comprised over 10 percent of respondents.

Table 1b shows percentage of respondents, by college, who had ever purchased or used an electronic textbook. Over 80 percent of students in the College of Business and Economics (CBE) had used an electronic textbook. Between 30 and 50 percent of students in each of the other colleges had used an electronic textbook.

\section{Estimation Strategy and Results}

Estimations determining what affects a student's likelihood of having purchased or used an electronic textbook take the form

$$
Y_{i c}{ }^{*}=\beta X_{i c}+\alpha Z_{i c}+\delta_{c}+\varepsilon_{i c}
$$

where $i$ is individual student and $c$ is college of enrollment. $Y_{i c}{ }^{*}$ is the latent propensity for a student to have purchased or used an electronic textbook. $X_{i c}$ represents student-level

\footnotetext{
${ }^{2}$ Students who had a high-school graduating class size of 1 were home-schooled. Large graduating classes are more common among students who reported attending a high school in an urban or suburban area.

${ }^{3}$ The survey question read "My professors think I should use an electronic textbook," and respondents answered on a scale of 1-5, from "Strongly Disagree" to "Strongly Agree." In this paper, students who answered 4 or 5 are combined into one "Agreed/Strongly Agreed" variable.
} 
demographic and background controls. (In estimations, the linear variable AGE is set equal to zero for students whose $A G E \_O V E R \_40$ variable is equal to 1.$) Z_{\text {ic }}$ represents controls regarding the attitudes of each student's professors towards electronic textbooks. $\delta_{c}$ represents fixed effects controls for college and $\varepsilon_{i c}$ is a random error term.

Since propensity to purchase an electronic textbook is latent and unobserved, $Y_{i c}$ is defined as a dummy variable equal to 1 if student $i$ purchases an electronic textbook and 0 otherwise. $\quad \varepsilon_{i c}$ in Equation (1) is logistically distributed and maximum likelihood logit estimations of the equation

$$
\mathrm{P}\left(Y_{i c}=1 \mid X_{i c}, Z_{i c}\right)=\Lambda\left(\beta X_{i c}+\alpha Z_{i c}+\delta_{c}\right)
$$

are estimated.

Table 2 shows marginal effects from logit estimations of Equation (2) on the population of all surveyed students. ${ }^{4}$ In Column 1, only student demographic and background controls are included on the right-hand-side. Significantly negative marginal effects on AGE and AGE_OVER_40 indicate that younger students are more likely to have purchased or used an electronic textbook. Students from larger high schools, students financing their educations through loans and/or scholarships, and students who own either a laptop or a desktop computer are significantly more likely to have purchased or used an electronic textbook. ${ }^{5}$

Column 2 adds fixed effects for college, to control for the between-college differences in use of an electronic textbook shown in Table 1b. The dummy representing College of Letters, Arts, and Social Sciences (CLASS) is omitted for identification purposes. Students from four colleges - the College of Business and Economics, the College of Engineering, and College of

\footnotetext{
${ }^{4}$ Marginal effects are taken at estimations' sample means.

${ }^{5}$ Preliminary estimations included an interaction of COMPUTER_OWN_DESKTOP and

COMPUTER_OWN_LAPTOP. The coefficient on the interaction term was insignificant.
} 
Science, and the College of Agricultural \& Life Sciences—are significantly more likely to have used an electronic textbook than students from CLASS. Many controls which were significant in Column 1 are insignificant in Column 2. AGE, AGE_OVER_40, and RESOURCES_SCHOLARSHIPS become insignificant, suggesting that younger students and students who receive scholarships are more likely to have used electronic textbooks because they are enrolled in colleges where students are more likely to use them. Ownership of either a desktop or a laptop computer is no longer significantly correlated with use of an electronic textbook. Students receiving financial aid and students from larger high schools remain significantly more likely to have purchased or used an electronic textbook.

Column 3 adds controls for professors' attitudes towards electronic textbooks. Students who have had professors who either "agree" or "strongly agree" with the use of electronic textbooks are more likely to have used electronic textbooks, and those whose professors have "strongly disagreed" with the use of electronic textbooks are less likely to have used them. RESOURCES_FINANCIAL_AID and HIGH_SCHOOL_CLASS_SIZE remain significantly positive. COMPUTER_OWN_DESKTOP becomes significantly positive again, after having been insignificant in Column 2.

Table 2 thus suggests that students from larger high schools, students on financial aid, and students who own desktop computers are more likely to have purchased or used electronic textbooks. That students from larger high schools more frequently used electronic textbooks suggests that larger high schools expose their students to more computer-intensive modes of learning, giving their graduates lower marginal costs of using electronic textbooks in college. That students on financial aid are more likely to have used an electronic textbook suggests that electronic textbooks are an inferior good, i.e. students with more resources opt to purchase 
traditional bound textbooks rather than their less expensive electronic counterparts. The frequently significant coefficient on COMPUTER_OWN_DESKTOP indicates that desktop computers and electronic textbooks are complementary goods. Laptops, being so widely owned, are not the specific complement to electronic textbooks that desktop computers are.

Table 3 re-estimates Equation (2) on two subsets of the original sample. All 4 columns include fixed effects controls for college. Columns 1-3 show results when omitting Business and Economics (CBE) students, who are much more likely to have used electronic textbooks. In both columns, HIGH_SCHOOL_CLASS_SIZE, RESOURCES_FINANCIAL_AID and COMPUTER_OWN_DESKTOP remain significantly positive. AGE_OVER_40 is significantly negative in both columns.

Columns 3-4 include CBE students but limit the sample to students under the age of 30. Larger high school and receiving financial aid are, once again, significantly positive in all three columns, and COMPUTER_OWN_DESKTOP is significant in Column 4. Among these younger students, graduates of private high schools and students receiving scholarships are significantly more likely to have used electronic textbooks. Column 4 also shows significant evidence that female students are significantly more likely to have used electronic textbooks. ${ }^{6}$

In sum, Tables 2 and 3 show strong, significant, and persistent evidence that students on financial aid and students from larger high schools are more likely to have purchased or used electronic textbooks. These findings suggest, respectively, that e-textbooks are inferior goods, and that students from larger high schools (which are usually located in cities or suburbs) may have been exposed to more computer-intensive modes of learning. There is some evidence that students who own desktop computers are more likely to have used an electronic textbook,

\footnotetext{
${ }^{6}$ We also performed estimations that included a measure of each student's personal price elasticity, which was created via a one-factor loading from four different survey questions asking about students' willingness to search for low prices on textbooks. The measure of personal price elasticity was never significant in any estimation.
} 
suggesting that desktops and e-textbooks are complementary goods. And university-level factors—such as college of enrollment and professor attitudes towards electronic textbookssignificantly influence whether students have used them.

\section{Conclusions and Future Research}

This paper examines what factors affect college students’ likelihood of having purchased or used an electronic textbook. There are strong, significant, and persistent results showing that students from larger high schools and students who own desktop computers are more likely to have used an electronic text, and some less-persistent results showing that younger students are more likely to have used one. These results jointly suggest that experience with and technical competence with information technology increase students' use of e-textbooks. Additionally, students paying for their education with scholarships and loans are more likely to have used an electronic text, suggesting that e-textbooks are inferior goods, in the strict economic sense. Putting these findings together, as technical competence with information technology expands, as it surely will, and as the cost of college continues to rise, we would expect the demand for etextbooks to rise.

There is a strong relationship between college of enrollment and having used an electronic textbook. Students in four arguably more-technical colleges-Business and Economics, Science, Engineering, and Agriculture and Life Sciences-are more likely to have used an electronic text than are students in the College of Letters, Arts and Social Sciences. Results are especially strong for the College of Business and Economics, where over $80 \%$ of the students report use of an electronic text, possibly because some required courses in the college often use electronic text materials. 
Results also persistently show that professor attitudes towards electronic textbooks significantly affect students' use of them. The high rate of e-textbook use in the CBE, where use of some e-textbooks are required, and evidence of a distaste among professors in general for etextbooks (Nelson, 2008b), jointly suggest that e-textbook use may increase as professors' attitudes towards them change. Therefore, trends in competence with information technology, college costs, and professorial and institutional attitudes towards electronic textbooks suggest that rates of e-textbook use will increase over time. We are interested in this as a topic of future research, perhaps with a panel dataset. 


\section{References}

Association of American Publishers. (2012). AAP monthly snapshot, January 2012. March 30. http://www.publishersweekly.com. Accessed April 12, 2012.

Baker-Eveleth, L., Miller, J. R. \& Tucker, L. (2011). Lowering Business Education Cost with a Custom Professor-written Online Text. Journal of Education for Business, 86(4), 248252.

Beezer, R. (2009). The truly free textbook. EduCause Review, 44(1), 23-24.

Blumenstyk, G. (2008). To cut costs, ought colleges look to for-profit models?, Chronicle of Higher Education, June 13. pp. A19-20.

Carlson, S. (2005, February 11). Online textbooks fail to make the grade, Chronicle of Higher Education, pp. A35-36.

Chaker, A. M. (2006, September 28). Efforts mount to cut costs of textbooks: As prices rise at twice the rate of inflation, states pass laws to encourage cheaper alternatives. , The Wall Street Journal, pp. 1-3.

Christopher, L. C. (2009). Academic Publishing: Digital alternatives to expensive textbooks. Seybold Online, 8(19), 11-14. Retrieved from http://www.seyboldreport.com/bookpublishing/academic-publishing-digital-alternatives-expensive-textbooks

Crawford, W. (2006). Why aren’t ebooks more successful? . EContent, 29, October. 44.

Dudley, B. (2011). Kindle So-So for students. UW Study Concludes. Retrieved from http://seattletimes.nwsource.com/html/technologybrierdudleysblog/2014937738_kindle_s o-so_for_students_uw_s.html

Foderaro, L. W. (2010, 10-20-2010). In a Digital Age, Students Still Cling to Paper Textbooks., The New York Times. Retrieved http://www.nytimes.com/2010/10/20nyregion/20textbooks.

Graham, J. (2011,). Inkling opens textbooks on the iPad, USA Today. August 3.

Hampson, K. (2011). Interview: Ed tech leader, Jon Williams of Flat World Knowledge. http://bx.businessweek.com/higher-

education/view?url=http\%3A\%2F\%2Fhighereducationmanagement.wordpress.com\%2F2 011\%2F05\%2F02\%2Finterview-ed-tech-leader-jon-williams-of-flat-worldknowledge\%2F. May 2.

Kang, S. (2004). New options for cheaper textbooks: Under fire for high prices, publishers push alternatives; renting your chem book, The Wall Street Journal, August 24. p. 1.

Kingsbury, A., \& Galloway, L. (2006). Textbooks enter the digital era. U.S. News and World Report, 141, October 16. 63-65.

Krapfl, A. (2011). E-textbook Sales off to a Good Start., Inside Iowa State. Retrieved from http://www.iastate.inside.edu/2011/1017/text.php

Larson, R. (2002). E-enabled textbooks: Lower cost, higher functionality. Campus Technology, 05. Retrieved from http://campustechnology.com/articles/39043/

Marklein, M.B. (2012). Groups target textbook prices to rein in college costs. USA TODAY. February 2, 2012. http://www.usatoday.com. Accessed April12, 2012.

Nelson, M.R. (2008a). E-books in higher education: Nearing the end of the era of hype? EDUCAUSE Review 43 (March/April). http://www.educause.edu. Accessed, April 12, 2012.

Nelson, M. R. (2008b). Is higher education ready to switch to digital course materials? Chronicle of Higher Education, 55, November 28. A29. 
National Association of College Stores. (2010). E-Books, E-Readers slow to catch on with college students.” Press Release, October 27.

Office, U.S. Government Accountability. (2005). College Textbooks: Enhanced Offerings Appear to Drive Recent Price Increases. Report to Congressional Requesters, July.

Perez-Pena, R. (2009). Rocky Mountain News Fails to Find Buyer and Will Close. The New York Times. February 26.

Rachlin, N. (2011). Digital textbooks slow to catch on; Lower prices fail to spur sales, but study hints at boost with rise of tablets, The International Herald Tribune. June 5.

Rampell, C. (2008, May 2). Free textbooks: An online company tries a controversial publishing model, Chronicle of Higher Education, pp. 14-15.

Ravid, G., Kalman, Y.M., Rafaeli, S. (2008). Wikibooks in Higher Education: Empowerment through Online Distributed Collaboration. Computers in Human Behavior, 24, 19131928.

Richman, D., James, A. (2009). Seattle P-I to publish last edition Tuesday. The Seattle PostIntelligencer. March 16.

Roberts, S. (2006). Costly textbooks draw scrutiny of lawmakers, The Wall Street Journal, April 25. p. 2.

Roso, L., Rosenwald, M.S. (2011). At Borders’ closing, everything on shelves is priced to go. The shelves, too. The Washington Post. April 17.

Schuetze, C.F. (2011). Textbooks finally take big leap to digital. The New York Times. November 23. http://www.nytimes.com/2011/11/24/world/americas. Accessed April 12, 2012.

Stewart, R. (2009). Some thought on free textbooks. EduCause Review, 44(1), 24-26.

US News and World Report Best Colleges, 2012 Edition (2012). http://colleges.usnews.rankingsandreviews.com/best-colleges. Accessed April 18, 2012. 
Table 1a

Summary Statistics

\begin{tabular}{|c|c|c|c|c|c|}
\hline & Obs & Mean & Std. Dev & Min & Max \\
\hline ETEXT_EVER_PURCHASED_OR_USED & 1098 & 0.445 & 0.497 & 0 & 1 \\
\hline$A G E$ (if 40 or under) & 1022 & 22.8 & 4.9 & 18 & 40 \\
\hline AGE_OVER_40 & 1098 & 0.069 & 0.254 & 0 & 1 \\
\hline FEMALE & 1098 & 0.582 & 0.493 & 0 & 1 \\
\hline HIGH_SCHOOL_CLASS_SIZE & 1098 & 266.7 & 196.6 & 1 & 800 \\
\hline HIGH_SCHOOL_PRIVATE & 1098 & 0.074 & 0.262 & 0 & 1 \\
\hline COLLEGE_EXPENSES_SHARE_YOUR_RESP & 1098 & 0.659 & 0.372 & 0 & 1 \\
\hline RESOURCES_FINANCIAL_AID & 1098 & 0.648 & 0.478 & 0 & 1 \\
\hline RESOURCES_SCHOLARSHIPS & 1098 & 0.677 & 0.468 & 0 & 1 \\
\hline RESOURCES_WORK_FULL_OR_PART_TIME & 1098 & 0.557 & 0.497 & 0 & 1 \\
\hline RESOURCES_PARENTS_FAMILY & 1098 & 0.463 & 0.499 & 0 & 1 \\
\hline COMPUTER_OWN_LAPTOP & 1098 & 0.926 & 0.262 & 0 & 1 \\
\hline COMPUTER_OWN_DESKTOP & 1098 & 0.377 & 0.485 & 0 & 1 \\
\hline ETEXT_PROFS_STRONGLY_DISAGREE & 1084 & 0.085 & 0.279 & 0 & 1 \\
\hline ETEXT_PROFS_AGREE_OR_STRONGLY_AGREE & 1084 & 0.059 & 0.236 & 0 & 1 \\
\hline COLLEGE_AG_LIFE_SCIENCES & 1090 & 0.098 & 0.298 & 0 & 1 \\
\hline COLLEGE_ART_ARCHITECTURE & 1090 & 0.049 & 0.215 & 0 & 1 \\
\hline COLLEGE_BUSINESS_ECONOMICS & 1090 & 0.126 & 0.332 & 0 & 1 \\
\hline COLLEGE_EDUCATION & 1090 & 0.134 & 0.341 & 0 & 1 \\
\hline COLLEGE_ENGINEERING & 1090 & 0.159 & 0.366 & 0 & 1 \\
\hline COLLEGE_ARTS_LETTERS_SOCSCI & 1090 & 0.269 & 0.444 & 0 & 1 \\
\hline COLLEGE_NATURAL_RESOURCES & 1090 & 0.069 & 0.253 & 0 & 1 \\
\hline COLLEGE_SCIENCE & 1090 & 0.097 & 0.296 & 0 & 1 \\
\hline
\end{tabular}

Table 1b

ETEXT_EVER_PURCHASED_OR_USED, BY COLLEGE

Agriculture \& Life Sciences

$\begin{array}{rr}\text { Obs } & \text { Mean } \\ 107 & 0.449 \\ 53 & 0.396 \\ 137 & 0.803 \\ 146 & 0.315 \\ 173 & 0.462 \\ 293 & 0.369 \\ 75 & 0.387 \\ 106 & 0.425\end{array}$


Table 2

Estimation Results

Absolute value of $z$ statistics included

${ }^{*}$ significant at $10 \%$; ${ }^{* *}$ significant at $5 \%$; ${ }^{* *}$ significant at $1 \%$

\begin{tabular}{|c|c|c|c|}
\hline & 1 & 2 & 3 \\
\hline \multirow[t]{2}{*}{$A G E$} & -0.009 & -0.006 & -0.006 \\
\hline & $-2.20 * *$ & -1.47 & -1.45 \\
\hline \multirow[t]{2}{*}{$A G E \_O V E R \_40$} & -0.311 & -0.191 & -0.207 \\
\hline & $-2.52 * *$ & -1.47 & -1.55 \\
\hline \multirow[t]{2}{*}{ FEMALE } & -0.003 & 0.031 & 0.035 \\
\hline & -0.09 & 0.87 & 0.98 \\
\hline \multirow[t]{2}{*}{ HIGH_SCHOOL_CLASS_SIZE (100s) } & 0.020 & 0.021 & 0.020 \\
\hline & $2.43^{* *}$ & $2.48^{* *}$ & $2.32^{* *}$ \\
\hline \multirow[t]{2}{*}{ HIGH_SCHOOL_PRIVATE } & 0.077 & 0.096 & 0.084 \\
\hline & 1.29 & 1.56 & 1.33 \\
\hline \multirow[t]{2}{*}{ COLLEGE_EXPENSES_SHARE_YOUR_RESP } & -0.035 & 0.002 & 0.006 \\
\hline & -0.68 & 0.03 & 0.10 \\
\hline \multirow[t]{2}{*}{ RESOURCES_FINANCIAL_AID } & 0.081 & 0.108 & 0.109 \\
\hline & $2.34 * *$ & $2.93 * * *$ & $2.91 * * *$ \\
\hline \multirow[t]{2}{*}{ RESOURCES_SCHOLARSHIPS } & 0.064 & 0.056 & 0.047 \\
\hline & $1.76^{*}$ & 1.46 & 1.20 \\
\hline \multirow[t]{2}{*}{ RESOURCES_PARENTS_FAMILY } & -0.004 & -0.003 & -0.001 \\
\hline & -0.11 & -0.07 & -0.03 \\
\hline \multirow[t]{2}{*}{ RESOURCES_WORK_FULL_OR_PART_TIME } & 0.034 & 0.034 & 0.046 \\
\hline & 1.04 & 0.98 & 1.32 \\
\hline \multirow[t]{2}{*}{ COMPUTER_OWN_LAPTOP } & 0.135 & 0.091 & 0.101 \\
\hline & $2.12^{* *}$ & 1.39 & 1.51 \\
\hline \multirow[t]{2}{*}{ COMPUTER_OWN_DESKTOP } & 0.081 & 0.060 & 0.067 \\
\hline & $2.24^{* *}$ & 1.57 & $1.74^{*}$ \\
\hline \multirow[t]{2}{*}{ COLLEGE_AG_LIFE_SCIENCES } & & 0.099 & 0.101 \\
\hline & & $1.72 *$ & $1.73^{*}$ \\
\hline \multirow[t]{2}{*}{ COLLEGE_ART_ARCHITECTURE } & & 0.038 & 0.066 \\
\hline & & 0.49 & 0.82 \\
\hline \multirow[t]{2}{*}{ COLLEGE_BUSINESS_ECONOMICS } & & 0.510 & 0.485 \\
\hline & & $7.93 * * *$ & $7.44 * * *$ \\
\hline \multirow[t]{2}{*}{ COLLEGE_EDUCATION } & & -0.009 & -0.013 \\
\hline & & -0.17 & -0.24 \\
\hline \multirow[t]{2}{*}{ COLLEGE_ENGINEERING } & & 0.123 & 0.131 \\
\hline & & $2.36 * *$ & $2.46^{* *}$ \\
\hline \multirow[t]{2}{*}{ COLLEGE_NATURAL_RESOURCES } & & 0.059 & 0.057 \\
\hline & & 0.87 & 0.82 \\
\hline \multirow[t]{2}{*}{ COLLEGE_SCIENCE } & & 0.097 & 0.105 \\
\hline & & $1.64^{*}$ & $1.75^{*}$ \\
\hline \multirow[t]{2}{*}{ PROFS_STRONGLY_DISAGREE } & & & -0.154 \\
\hline & & & $-2.47 * *$ \\
\hline \multirow[t]{2}{*}{ PROFS_AGREE_STRONGLY_AGREE } & & & 0.240 \\
\hline & & & $3.06 * * *$ \\
\hline Observations & 1092 & 1084 & 1070 \\
\hline Pseudo- $R^{2}$ & 0.024 & 0.083 & 0.095 \\
\hline
\end{tabular}


Table 3

Estimation Results

Absolute value of $\mathrm{z}$ statistics in brackets

${ }^{*}$ significant at $10 \%$; ${ }^{* *}$ significant at $5 \%$; ${ }^{* *}$ significant at $1 \%$

\begin{tabular}{|c|c|c|c|c|}
\hline & \multicolumn{2}{|c|}{ NON-CBE } & \multicolumn{2}{|c|}{ UNDER AGE 30} \\
\hline & 1 & 2 & 3 & 4 \\
\hline \multirow[t]{2}{*}{$A G E$} & -0.007 & -0.007 & -0.010 & -0.007 \\
\hline & -1.57 & -1.51 & -1.39 & -1.03 \\
\hline \multirow[t]{2}{*}{ AGE_OVER_40 } & -0.220 & -0.227 & & \\
\hline & $-1.68 *$ & $-1.70^{*}$ & & \\
\hline \multirow[t]{2}{*}{ FEMALE } & 0.027 & 0.033 & 0.057 & 0.068 \\
\hline & 0.74 & 0.89 & 1.46 & $1.69 *$ \\
\hline \multirow[t]{2}{*}{ HIGH_SCHOOL_CLASS_SIZE(100s) } & 0.023 & 0.021 & 0.020 & 0.020 \\
\hline & $2.63 * * *$ & $2.44 * *$ & $2.09 * *$ & $2.04^{* *}$ \\
\hline \multirow[t]{2}{*}{ HIGH_SCHOOL_PRIVATE } & 0.092 & 0.078 & 0.136 & 0.121 \\
\hline & 1.49 & 1.25 & $2.02 * *$ & $1.77^{*}$ \\
\hline \multirow[t]{2}{*}{ COLLEGE_EXPENSES_SHARE_YOUR_RESP } & 0.015 & 0.020 & 0.021 & 0.029 \\
\hline & 0.26 & 0.36 & 0.36 & 0.49 \\
\hline \multirow[t]{2}{*}{ RESOURCES_FINANCIAL_AID } & 0.111 & 0.112 & 0.100 & 0.095 \\
\hline & $2.98 * * *$ & $2.98 * * *$ & $2.44 * *$ & $2.27^{* *}$ \\
\hline \multirow[t]{2}{*}{ RESOURCES_SCHOLARSHIPS } & 0.035 & 0.027 & 0.072 & 0.072 \\
\hline & 0.91 & 0.69 & $1.69 *$ & $1.66^{*}$ \\
\hline \multirow[t]{2}{*}{ RESOURCES_PARENTS_FAMILY } & -0.002 & 0.000 & 0.007 & 0.011 \\
\hline & -0.05 & 0.00 & 0.17 & 0.26 \\
\hline \multirow[t]{2}{*}{ RESOURCES_WORK_FULL_OR_PART_TIME } & 0.019 & 0.031 & 0.037 & 0.047 \\
\hline & 0.53 & 0.88 & 0.98 & 1.24 \\
\hline \multirow[t]{2}{*}{ COMPUTER_OWN_LAPTOP } & 0.078 & 0.087 & 0.019 & 0.020 \\
\hline & 1.24 & 1.35 & 0.25 & 0.26 \\
\hline \multirow[t]{2}{*}{ COMPUTER_OWN_DESKTOP } & 0.067 & 0.073 & 0.066 & 0.074 \\
\hline & $1.75^{*}$ & $1.87^{*}$ & 1.55 & $1.71 *$ \\
\hline \multirow[t]{2}{*}{ COLLEGE_AG_LIFE_SCIENCES } & 0.096 & 0.098 & 0.111 & 0.112 \\
\hline & $1.73^{*}$ & $1.75^{*}$ & $1.79 *$ & $1.79 *$ \\
\hline \multirow[t]{2}{*}{ COLLEGE_ART_ARCHITECTURE } & 0.034 & 0.061 & 0.051 & 0.077 \\
\hline & 0.45 & 0.79 & 0.62 & 0.93 \\
\hline \multirow[t]{2}{*}{ COLLEGE_BUSINESS_ECONOMICS } & & & 0.522 & 0.501 \\
\hline & & & $7.74^{* * *}$ & $7.32 * * *$ \\
\hline \multirow[t]{2}{*}{ COLLEGE_EDUCATION } & -0.008 & -0.012 & -0.038 & -0.042 \\
\hline & -0.15 & -0.22 & -0.59 & -0.63 \\
\hline \multirow[t]{2}{*}{ COLLEGE_ENGINEERING } & 0.116 & 0.124 & 0.134 & 0.145 \\
\hline & $2.29 * *$ & $2.41^{* *}$ & $2.35^{* *}$ & $2.50 * *$ \\
\hline \multirow[t]{2}{*}{ COLLEGE_NATURAL_RESOURCES } & 0.057 & 0.055 & 0.061 & 0.054 \\
\hline & 0.87 & 0.83 & 0.81 & 0.70 \\
\hline \multirow[t]{2}{*}{ COLLEGE_SCIENCE } & 0.092 & 0.101 & 0.121 & 0.124 \\
\hline & 1.63 & $1.74^{*}$ & $1.87^{*}$ & $1.89 *$ \\
\hline \multirow[t]{2}{*}{ PROFS_STRONGLY_DISAGREE } & & -0.150 & & -0.120 \\
\hline & & $-2.44^{* *}$ & & $-1.84 *$ \\
\hline \multirow[t]{2}{*}{ PROFS_AGREE_STRONGLY_AGREE } & & 0.230 & & 0.275 \\
\hline & & $2.78^{* * *}$ & & $3.26^{* * *}$ \\
\hline Observations & 948 & 935 & 912 & 901 \\
\hline Pseudo- $\mathrm{R}^{2}$ & 0.029 & 0.042 & 0.085 & 0.098 \\
\hline
\end{tabular}

